\title{
These are dresses that are stitched with dreams: Struggle, Freedom and the Women of the Clothing and Textile Industry of the Western Cape
}

\section{Siona O'Connell}

\begin{abstract}
The ordinary archive of the racially oppressed in South Africa offers a critical lens through which to interrogate notions of resistance, subjectivities and freedom. This paper considers these questions by examining the phenomenon that is the annual Spring Queen pageant which, for more than 46 years, has proffered a potential real-life 'Cinderella' experience to the poorly-paid, industrious women of the Western Cape's clothing and textile trade. Initiated by their union, the Southern African Clothing and Textile Workers' Union (SACTWU) in the late 1970 s as a response to worker agitation, the social significance of the pageant runs incontrovertibly deeper than a one-night spectacle. Despite a dearth of subject-specific formal research, this paper draws on available literature analysing the impact of apartheid on culture and society in South Africa, along with extensive relevant media coverage of the Spring Queen pageant, and personal interviews with those involved and impacted. It goes beyond describing the experiences of working class 'coloured' women who contributed to the anti-apartheid struggle through their union activities. It also highlights how an enduring annual gala event has afforded the 'invisible' clothing production line workers who underpin a multi-billion rand South African export industry an opportunity to envision a yet-to-be realised freedom, while reflecting the power and resilience of the ordinary to transform in extraordinary times.
\end{abstract}

Keywords: Spring Queen, clothing and textile industry, Cape Town, pageant, Southern African Clothing and Textile Workers' Union (SACTWU), apartheid, freedom, labour 
Working in a factory is not a very glamorous job. It's hard work with long hours. But for that one night, we are supermodels. And there is no better feeling in the world. [But] there is more to the pageant than factory workers dressing up. All the clothing we model is local. It is important that this is promoted, because if clothing is manufactured here, it leads to more jobs in our communities (Emmerencia Jones, Spring Queen 2014).

Spring Queen has its own historical energy behind it that drives it. But for SACTWU, the most important thing is the link that we can make in the public eye about local clothing workers and their jobs (Eppel 2012).

\section{Introduction}

Being raised by a mother who shopped for the family's clothing and linen in Cape Town's factory outlets, with Saturday mornings spent rummaging through items deemed 'seconds', discarded and not quite up to scratch, 'hitting the jackpot' meant finding that perfect item after foraging in jumbled piles of mismatched clothing - notwithstanding the bright circular stickers highlighting its defects. She, along with several immediate and extended family members, worked in the Western Cape clothing and textile industry, part of a cohort of tens of thousands of 'coloured' women on whose shoulders this multi-billion rand contributor to the provincial and national economy rested. Newspaper coverage of the Spring Queen pageant in The Herald and The Sunday Times Extra newspapers was eagerly consumed by everyone, laying the groundwork for an understanding, even in the very young, of the importance of the event to 'coloured' people.

'Colouredness', says Brian O'Connell (2015), former rector and vicechancellor of the University of the Western Cape, may be rooted in inferiority thanks to the historical occupation by the Dutch of the Western Cape, but importantly - also displays a tenacious ability to 'find a way in the shadows'. He notes: 'There is consensus in the world currently that Africa is the cradle of humankind and the migrations from Africa are very interesting, particularly the migrations southwards. The people who migrated furthest south became known as the San and later on another group migrated and they became known 


\section{Siona O’Connell}

as the Khoe. And Khoe-San settled in large parts of South Africa and particularly, in the Western Cape. And along comes three boats from Holland and their lives change. The Dutch came to occupy and to dominate. There were sexual unions, resulting in offspring that is neither one or the other, and this is the origin of the concept, or the group of people who would later become named as coloured. These new people then found themselves in a position of inferiority, relative to the masters, and the ways in which these new people had to engage in order to make a go of things was to find the ways in the shadows, from which they could emerge when there was some strategic matter that they wished to achieve'1.

The Spring Queen pageant, initiated by the Southern African Clothing and Textile Workers' Union 46 years ago, is exactly such a repudiation of 'living in the shadows' and on the margins, offering a critical opportunity to consider the particularities of colouredness in South Africa, but also of other lives and bodies falling outside of a white, patriarchal norm. In this context, it is impossible to ignore the impact on workers of an industry negatively affected by trade liberalisation and growing international competition. Not only did the women earn low wages for long hours of work. They also lived in fear of imminent retrenchments, with little prospect of alternative employment opportunities should they lose their jobs, threatening the welfare of entire families (Van der Westhuizen 2006: 13, 14).

In light of the complexity of the histories detailed above, this reflexive paper seeks, on the following four levels, to demonstrate the wide-ranging and largely unstudied significance of the Spring Queen pageant - and how it affords otherwise unheralded workers the chance to 'dream', to imagine true freedom in a contemporary South Africa:

- It foregrounds an historical and cultural insight into the lives of working class black and 'coloured' women in Cape Town.

- It situates the pageant against a background of how apartheid determined the development of black and 'coloured' communities, and their struggle to be anything but racialised victims.

\footnotetext{
${ }^{1}$ See as well Kamies, N. 2019. Shame and Respectability: A Narrative Enquiry into Cape Town's 'Coloured' Families through Photographs, Cultural Practices and Oral Histories (c. 1950 to 2016). Doctoral Thesis University of Pretoria, Pretoria.
} 
Struggle, Freedom and the Women of the Clothing and Textile Industry

- It affords political significance to the ordinary archive.

- It gives a voice to the women who would, in all likelihood, not otherwise be heard.

\section{Methodology}

Conducting a literature review of how an archive of the Spring Queen pageant can be examined for insights into the past and present lives of those oppressed by apartheid is complicated by the fact that most of the specific recorded research is my own. I spent the past seven years working closely with clothing workers, forging a deep relationship with the Southern African Clothing and Textile Workers' Union (SACTWU). I curated an exhibition, Sequins, Self and Struggle, which was first presented at the University of Cape Town in 2013, and the following year produced the film, Spring Queen. Both were attended by hundreds of clothing workers. This relationship allowed me to scrutinise union archives and afforded me intimate access to the day-to-day lives of no less than 120 women, aged between 20 and 60, who are members of this union, and/or who themselves participated in the SACTWU Spring Queen pageant. I was shown faded newspaper cuttings, pageant sashes and crowns, and sometimes even the winning dresses. I also attended numerous pageants at factory level and finals, when the latter was held at its historical 'home', the Good Hope Centre, at the edge of District $\mathrm{Six}^{2}$ before being moved in 2016 amid considerable controversy - to the Athlone Stadium on the Cape Flats, some 20 kilometres from the city centre. I was also invited to judge the pageant for three years in 2016, 2017 and 2019.

This data and personal experience were augmented with information from historical accounts, relevant online blogs, opinion pieces and extensive more recent newspaper clippings, many of which proved particularly illuminating as they served to highlight the socio-political landscape of the specific year of particular pageants. For example, in the Sunday Times Extra

${ }^{2}$ District Six was home to a mixed community of freed slaves, merchants, artisans, labourers and immigrants which, in 1966, was declared a white area in terms of the Group Areas Act of 1950. More than 60000 people were forcibly removed to outlying areas of Cape Town and their entire neighbourhood was bulldozed to the ground. 
of December 16 1990, Spring Queen winner Colleen Adams shared the frontpage attention with articles about eviction and the freeing of prisoners, both of which, I contend, have bearing on the pageant and its participants.

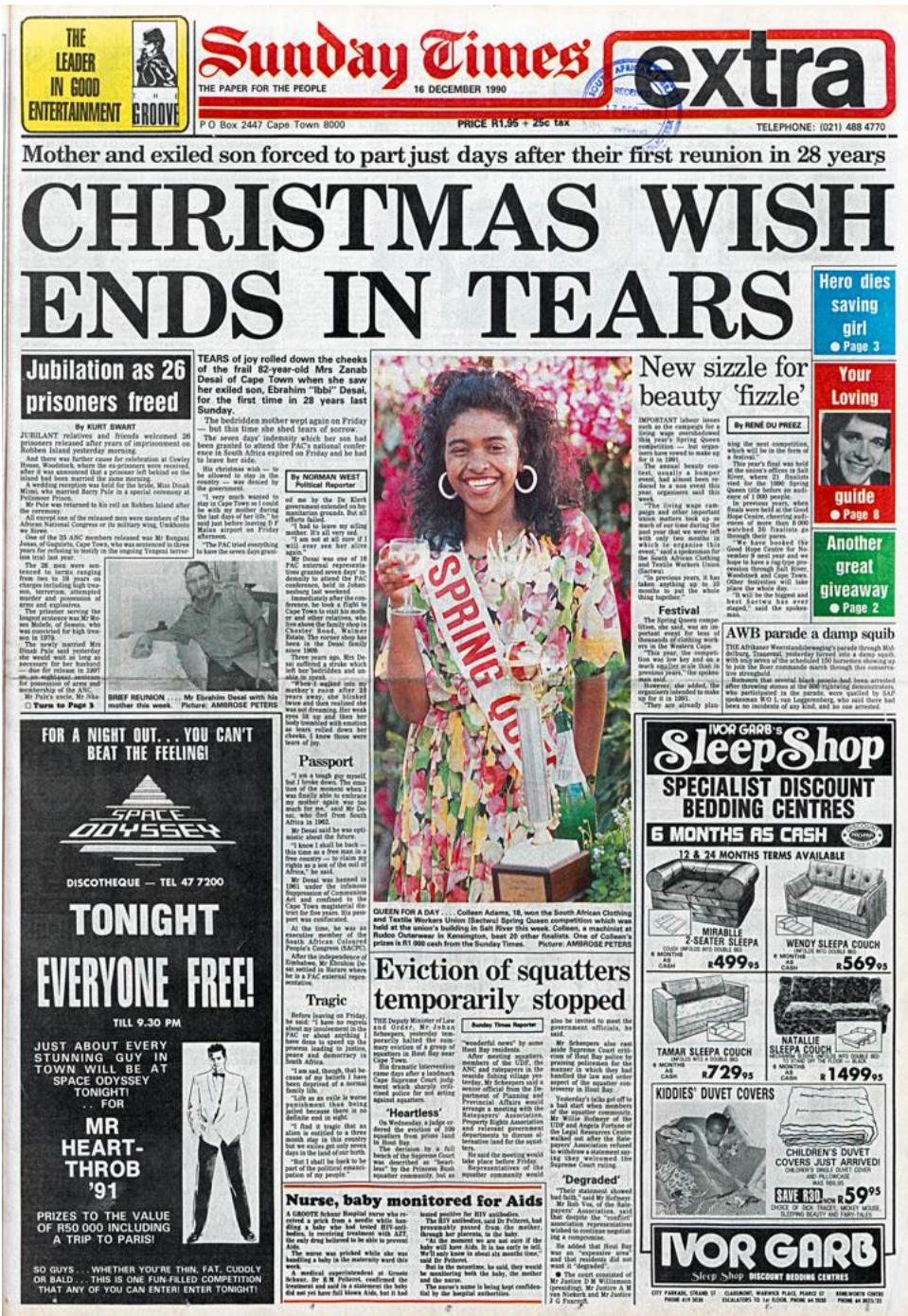

Image 1: Sunday Times Extra front page, 16 December 1990. Courtesy of SACTWU. 
As columnist, writer and online interviewer Terry Bell notes (Bell 2012): 'Real Cinderella moments tend to contain a social bite, for all their contradictions, because they retain their moorings in reality. At best, they amount to sticking two fingers up at the world of exploiters and oppressors, even if this remains an inside joke, little observed beyond the participants. So it is probably no coincidence that the best example of this emerged in Cape Town in the wake of the 1976 anti-apartheid uprisings'.

Although this paper foregrounds a union event, I will not discuss the history of the union or of labour in South Africa in any depth. Instead, the content relies heavily on narrative inquiry derived directly from the women involved in the Spring Queen experience to suggest that they afford an opportunity to imagine lives of defiance and resilience. Further relevant data was sourced via interviews with major players in the SACTWU space and a former South African Minister of Finance able to supply both personal and professional input.

\section{History}

The first clothing and textile union in South Africa was the Witwatersrand Tailors' Association, in 1918, just five years after the Native Land Act of 1913 (Alegi 2008:33). Shortly after, the name of the union was changed to the Garment Workers Union of South Africa in 1929. Alegi makes the point that union divisions were 'exacerbated by the actions of capitalist employers and the impact of racist legislation in the 1950s and 1960s' (ibid). Among a plethora of laws, the Group Areas of Act of 1950 would have a significant impact on the lives of clothing workers in Cape Town, with many who would have been employed in nearby factories, such as Ensign Clothing on the edge of District Six and Rex Trueform in Salt River, being evicted from their homes and relocated to areas on the distant Cape Flats. A large number of the women interviewed for this and similar research spoke of having to drop out of school to support their families as living costs escalated thanks to breadwinners having to bear the additional costs related to residing long distances from their places of employment.

The pageant had its roots in the violent political tumult of the late 1970s and early 1980s, framed by the militant trade unionism, the 1973 Durban Strikes and the 1976 Soweto Uprising. In Cape Town, garment workers took 


\section{Siona O’Connell}

to the streets in support of the uprising, participating in stayaways and boycotts such as those of Cape Town's Fatti's and Moni's pasta company, red meat and escalating bus fares. The period of defiance swept across the Cape Flats and contributed to the announcement of a clothing worker pageant by largely white factory management and the conservative, white-controlled Garment Workers Union of the Western Province (GWU), which was the largest single trade union in the country (Alegi 2008:35). SACTWU's Rachel Visser would go on to say that 'the reason they started the Spring Queen was to give these women something to shut up, something to be quiet about'.

For context, as I have written previously in respect of the 2013 exhibition, the pageant, one of the largest and longest-standing in history, attracts thousands of women who first participate in in-house events. A factory Queen is then chosen along with a first and second princess. The factory Queens represent their factories and participate in the semi-finals held at the SACTWU hall at the union head office. The women who make it through the semi-finals, usually between 40 and 60 , or sometimes more, proceed to compete in the grand affair that is the SACTWU Spring Queen competition held every November. The coveted title of the SACTWU Spring Queen, the Queen of Queens, is awarded, along with a first and second Princess, as well as a Miss Personality and a Miss Best Dressed. Van der Westhuizen (2006: 12) says these competitors, like clothing workers across South Africa, are 'geographically and racially differentiated', with coloured women predominating. Poor women of colour, she points out, have and still absorb the social costs of liberalisation, a truth illustrated very clearly by the case of this industry in the years since 1999, thanks to the negative impacts of trade deregulation and burgeoning international competition. It is against this background that I use the pageant as an armature to consider lives lived on all sorts of lines and margins, looking at Cape Town as a point of departure.

\section{Chasing the Fairytale}

In September 1993, a few months before the dawn of a democratic South Africa, an article in the New York Times declared that: 'Few countries in the world take pageants quite as seriously as South Africa' ${ }^{3}$. Most South Africans

${ }^{3}$ New York Times, 16 September 1993. See also Sarah Nuttall and Cheryl-Ann Michael (eds.): Senses of Culture: South African Culture Studies. Oxford (2000: 344 - 362). 
of the day will clearly recall the all-white Miss South Africa competitions as well as the black Miss Africa South pageants, the latter producing outrage when the 1970 first runner- up, Pearl Jansen, placed higher than her white Miss South Africa counterpart, Jillian Jessop. In Cape Town, however, there was the fiercely-contested Miss Spring Queen title, the local significance of which is succintly summed up by blogger Reyanah Slamdien (Seams of Society 2016): 'For many women factory workers who come from the Cape Flats, who are single mothers, who work in the exploitative, cheap labour-seeking clothing factory industry, the SACTWU Spring Queen and Fashion pageant becomes what Kathleen (Adams, Spring Queen 2010) calls her 'moment'. It is a moment of inclusion in the fashion industry as recognition for their often overlooked and unappreciated labour. It is also a moment of expression and transformation in representing themselves as something other than the stereotypical factory worker'.

Former South African Minister of Finance Trevor Manuel summed up the harsh reality behind the glittering facade when he recalled, in an interview (2012), that he, along with his mother and sisters, had all worked in a clothing factory. Pageants, he said, 'are always about the fairytales'. They are fairytales, because they don't exist, and 'there's nothing more so than the Spring Queen. There's a vast difference between the adulation that's so separated from the life of the women who work in the clothing and textile sector'. His view is significant in how it reflects the 'unrealness' of Miss Spring Queen, and the position taken in this paper that within apartheid South Africa, the event provided space for an imagination of how real freedom (free from domination) could look. In a News24 media article (Petersen 2015), Miss Spring Queen 2014, Emmerencia Jones, 41, from Manenberg, gets the chance to share her take on how the pageant gives a face to those behind the locally-produced garments which fill the racks of the country's retailers. She is quoted as follows: 'Working in a factory is not a very glamorous job. It's hard work with long hours. But for that one night, we are supermodels. And there is no better feeling in the world'. She goes on to say that being crowned is a memory she will cherish for life. At 40 years old, she finally got that 'fairytale' moment: 'All I remember is seeing my husband in the crowd, dancing and singing and laughing that his wife had won'.

Slamdien (2016) reiterates the point in her blog, where she says that 'for those continuously excluded and marginalised women, Spring Queen and the experience of dressing up and putting down the factory overall is a moment 


\section{Siona O’Connell}

of self-representation ... moving beyond the negative experiences and pejorative stereotypes of being a factory worker and living (on) the Cape Flats'. She quoted me on the subject at the time, when I stressed that while the pageant is just a moment, what's important is that it is a moment when the factory workers claim those two minutes on the ramp and know that, for once, they won't be fading into the background. As Bell (2012) wrote: 'The commercial, economic and, all too often, political agendas that intrude into the pageant pale into insignificance beside this desire to show, however briefly, that 'ordinary factory workers' can be as good as - if not better - than the queens of film and fashion who grace the screens and the covers of glossy magazines'. He adds: 'Even amid drudgery and disappointment, there can be Cinderella moments; times when there is a glimpse of what may be possible; times when even the humblest and most exploited may be able to indulge, however briefly, in the illusion of what a better life might really be'.

It is critical to situate this pageant in the city where it takes place. Cape Town, framed in overt and covert ways by the Castle of Good Hope. Rhodes Memorial the Houses of Parliament, District Six and other markers that serve as a reminder of the catastrophic nature of colonialism and apartheid as historical trauma, located in the present. It is a city that echoes the multiple divides found across South Africa. These include mushrooming gated suburbs and townships, and their inhabitants, existing in separate realities; shaped in part by an absence of a conduit to span these divisions. Critical intellectual and curator, Anthony Bogues (2010:39), who is concerned with the politics of the wound and of historical catastrophe, contends that catastrophes of this nature do not fade away into memories and history. The systems of domination and control enacted by apartheid brought about innumerable traumatic events, ensuring that the legacy of legalised racial power is embedded in the present of post-apartheid South Africa. The persistent and relentless racial, social, and economic divides are reminders that the legacies of apartheid are not safely bound by temporality, and that the limited mandate of the Truth and Reconciliation Commission (TRC) revealed the need for new interventions that bridge injustices of the past ${ }^{4}$. It is in this climate that Spring Queen intervenes; understanding that new tools and approaches are central to not only

${ }^{4}$ See Heidi Grunebaum's compelling book, Grunebaum, H. 2011. Memorializing the Past: Everyday Life in South Africa after the Truth and Reconciliation Commission. New Brunswick, NJ: Transaction Publishers. (pp. 138.) 
understanding histories and futures, but how these are imagined, performed, and theorised. In so doing, women of the machine line taking ownership of a fashion ramp is another kind of intellectual labour, one that engages with modes of life and the practices and possibilities of yet-to-be realised freedom, doing so through the work of the imagination.

\section{The Views from Cape Town's Tourist Bus}

Situated in Main Road, Salt River, Cape Town, a suburb sandwiched on the taxi route between hipster Observatory on the one end and Mowbray - home to many University of Cape Town students - on the other, are the SACTWU offices. The ubiquitous wind is indicative of the dusty and windy plains of the Cape Flats, an expansive area that is understood, at least on a local level, to be the place 'where coloured and black people live'. Salt River is in reach of the Flats, due in large part to its proximity to the taxi, rail and bus hubs that transport those from the Cape Flats to work in the city, then return them home late at night. Salt River (nor areas of the Cape Flats such as Bonteheuwel, Manenberg, Bishop Lavis or Hanover Park, among others), are the kind of neighbourhoods that will feature in a tourist brochure for the picture-perfect Mother City, Cape Town. After all, those who are tasked with designing applicable brochures and websites are spoilt for choice; Cape Town was named Design Capital of the World in 2014 and offers a panorama of vistas and delights, not least of all due to the iconic Table Mountain, white sandy beaches, and a world-renowned (and expensive) culinary scene. It's easy to imagine the experience for holidaymakers to this city, many of whom will take the red tourist buses around the Peninsula. The intoxicating effects of trips to a plethora of wine estates of the Western Cape is counterbalanced by a sobering ferry trip to Robben Island, infamous for its imprisonment of Nelson Mandela and other political prisoners during apartheid. Lest anyone forget about the 1820 British occupation of the Cape, the Robben Island ferry (a must-do for visitors who can afford the cost of the ferry trip to the island) will return its passengers to the quay of the shopping mecca of South Africa, named the Victoria and Alfred Waterfront. Here, tourists are among the minority who can easily afford much of the clothing on sale - made by women of the Flats. Ironically, this includes underwear, that most intimate of items, which will bring them within a thread's breath of the anonymous women on the machine 


\section{Siona O’Connell}

line who toiled to produce these pieces on the factory floor. SACTWU researcher Simon Eppel (2012) comments that there were approximately 53 000 clothing workers in South Africa at that time, with $94 \%$ broadly defined black, and more than $80 \%$ female. With each worker supporting an average five dependents, the disproportionate impact of job losses came to bear on these female-headed households. Yet the items they worked so hard to create, artfully displayed in shopping malls, reveal little of the complex background story - except for those few who care to scratch the surface.

Even before disembarking to shop, those aboard the ferry will be treated to the most spectacular view of Table Mountain, voted in 2011 as one of the world's new Seven Natural Wonders (BrandSouthAfrica 2011), echoing the experiences of European colonials centuries earlier. Many tourists will also schedule a visit to the famed Rhodes Memorial that sits just above the University of Cape Town's upper campus, a monument to British imperialist and mining magnate, Cecil John Rhodes. After tea and English muffins at the memorial coffee shop, they will be able to see Rhodes's view and his imprint, one that includes the graffitied ruins of his zoo and evidence of his introduction of plant and animal species (Shepherd 2018: 29). When the red tourist bus heads to the base of the mountain, some may choose to brave the walk, but most will take the cable car. The fact that they, unlike the majority of South Africans, can afford the cost of the ticket is due in part to favourable dollar, pound and euro exchange rates which make the local currency resemble Monopoly dollars. That it is also only the privileged few South Africans who can share the cable car is itself indicative of a society that is among the most unequal in the world. The panoramic vista from the top is awe-inspiring. It includes the harbour, Robben Island and, closer to the foot of the mountain, the city centre with the Houses of Parliament. And the pentagonal structure of the Castle of Good Hope, the foundations of which were laid in 1665 and built with the labour of local men and women, slaves and Dutch East India Company workers. The view from the mountain also reveals the exclusive, largely 'white' and upmarket Atlantic seaboard and the leafy green suburbs of Claremont, Newlands and Constantia, which stand in sharp contrast to the rest of the vista - the Cape Flats, established largely as a result of apartheid racebased forced removals. This is home to the majority of Cape Town's women of the garment and textile industry - the unseen, living on the margins and held hostage by all the social ills that have resulted from South Africa's colonial and apartheid past. 
Struggle, Freedom and the Women of the Clothing and Textile Industry

\section{The Women of the Union}

The Spring Queen brings to life people who makes the clothes that you wear. People that you don't see. Often those people are single mothers who have three or four children to care for plus aunt, uncle, niece and second cousin as well. They're predominantly from the Cape Flats and they sit in the factories every day from Monday to Friday. Sometimes on a Saturday and Sunday. They get up at 4:30 in the morning to take public transport whether it's rain or shine, and often have to dodge bullets on the Cape Flats. I don't want the Spring Queen to become the moment where we realise the job that we do. We're so desensitised by the fact that people lose their jobs that we don't realise what it means to ordinary workers. For us it's just another job loss. For them it's their livelihood (Fachmy Abrahams 2012. SACTWU union official).

The announcement of the pageant came via the weekly union publication, Clothes Line (ibid). Those behind it had tapped into the societal and cultural values of the people of the Cape Flats: pageants and performance were significant (Alegi 2008:36). It was in 1979 that the inaugural winner, Ursula Bredeveldt, was crowned Miss Spring Queen 1980 at Union Hall in Salt River. Mainstream media coverage was scant but enthusiastic support of the pageant was widespread among the workforce, their extended families and social networks, especially as it had broad appeal across age groups. Since that first event, for women in the industry it is the months between July and November - beginning after final wage negotiations in June and just before the traditional holiday season - when Spring Queen fever takes hold. The semi-finals usually take place in September or October which gives the finalists about six weeks to two months to practice and rehearse for the big night.

Whilst Spring Queen is a fashion pageant, it is however primarily a union event, one that brings together realms of pageantry, labour and labour relations, gender, race, and the challenges of the clothing trade. There are several factors that give rise to the event being one that is largely 'coloured'. These include the demographics of the Western Cape, the targeting of coloured women to work in the industry as far back as 1910 (they were a primary source 
Siona O'Connell

of low-income labour), as well as legacies of the designation of the Western Cape as a Coloured Labour Preference Area in 1954-1955 (Alegi 2008: 34).

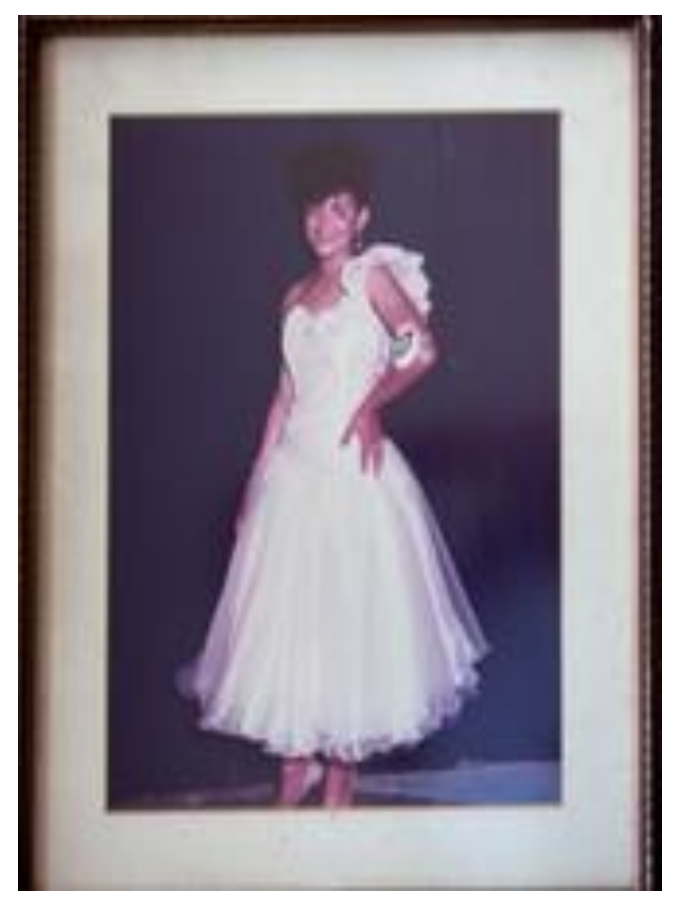

Image 2: A factory worker proudly enjoying her Spring Queen moment. Image courtesy of SACTWU 
Struggle, Freedom and the Women of the Clothing and Textile Industry

Pageant rules are minimal. Only union members may participate and, up to 2017, there was no age restriction. Anyone could enter: married women and mothers. It remains entirely possible to have daughters and mothers, aunts and nieces participating in the same union event. Petersen writes (2015) about contestant Zoe Hendricks, 14, of Grassy Park, who is vying for the inaugural Junior Spring Queen Pageant title 30 years after her mother took the main title. 


\section{Siona O’Connell}

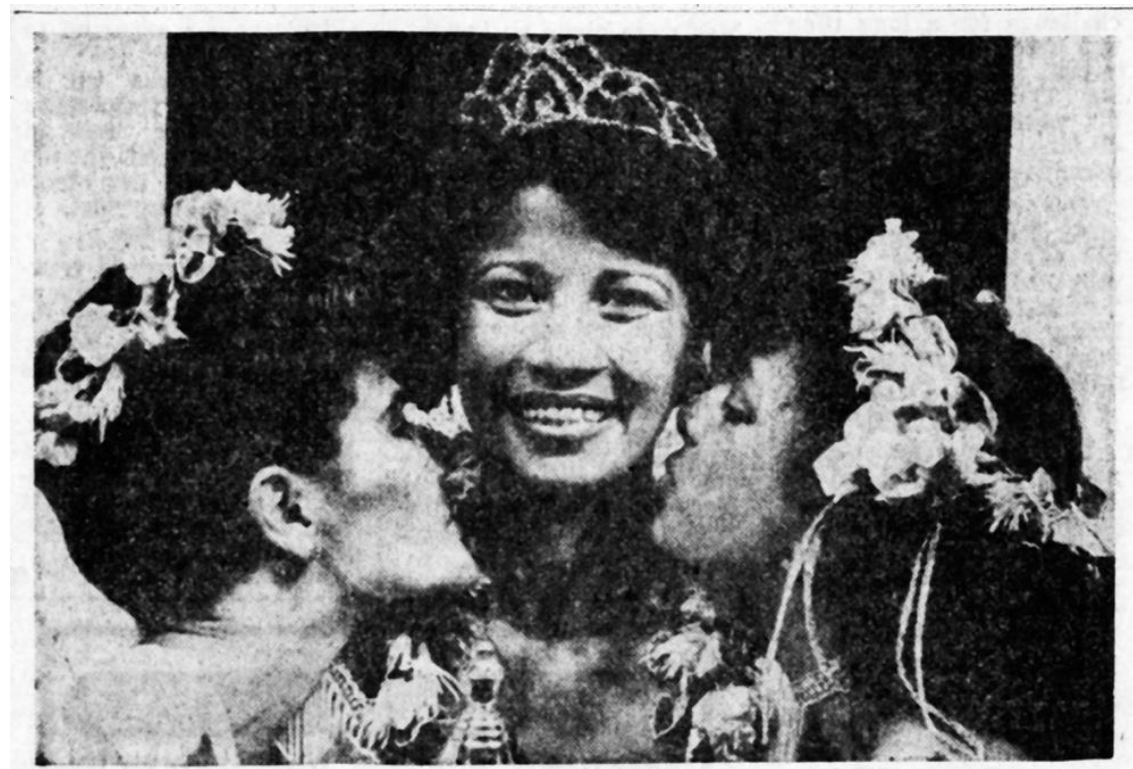

THE SPRING QUEEN for 1980 is Ursula Bredeveld, 22, of Mitchell's Plain. She won the crown at a glittering function at Salt River on Saturday night. Her princesses are Fatima Kamaldien, 19, left, and Mymoena Samsodien, 18, also of Mitchell's Plain. The contest was organised by the Garment Workers' Union of the Western Cape.

Image 3: The inaugural Spring Queen, Ursula Bredeveld, is crowned in 1980. Image courtesy of SACTWU 
Struggle, Freedom and the Women of the Clothing and Textile Industry

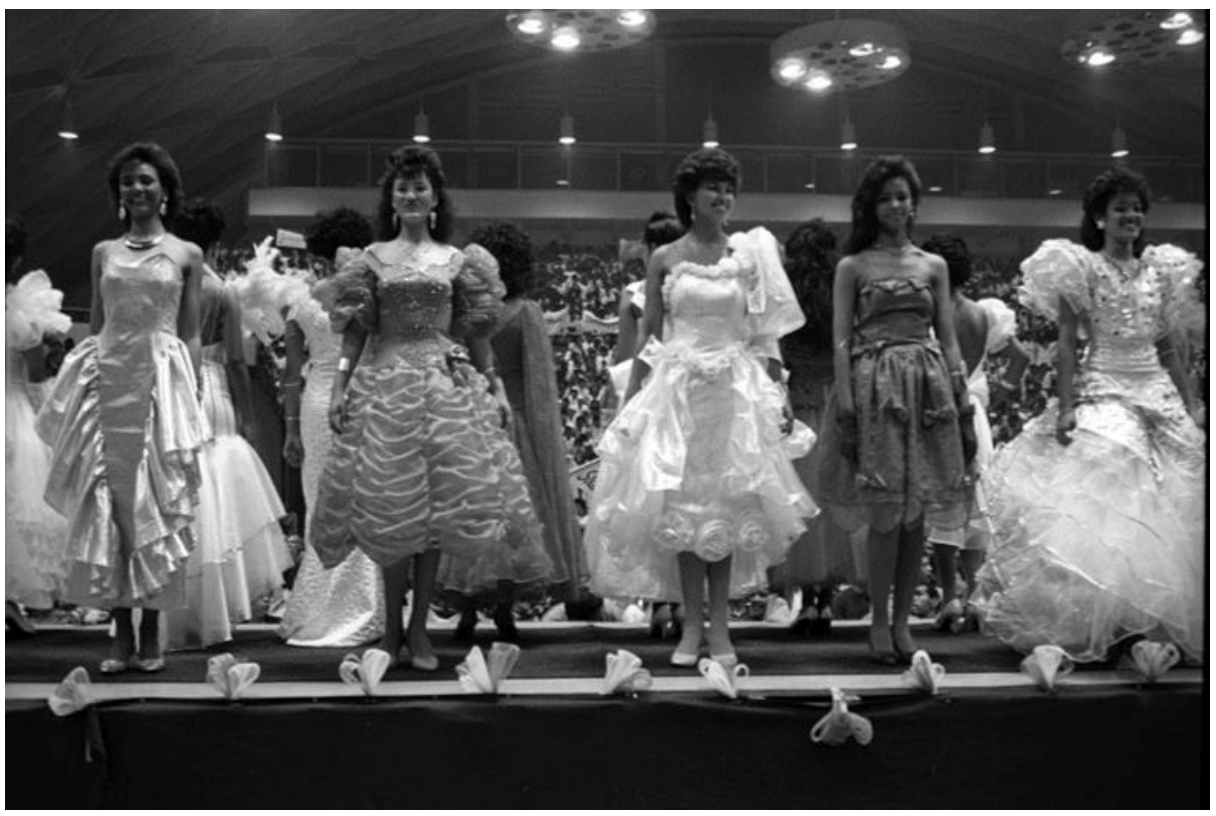

Image 4: Spring Queen finalists in 1989. Image courtesy of Benny Gool. 
In the black and white image on the previous page, Spring Queen finalists, taken in 1989 by anti-apartheid photographer Benny Gool, five women in over-the-top dresses line up, their broad smiles outshining the elaborate sleeves, ruching and lace of their dresses. Their supporters are visible in the background.

The 1980s is an important decade for the union, as well as the political landscape in Cape Town. It was the decade that bore witness to strikes and student boycotts, deaths and incarceration, not least being the Trojan Horse incident in in Athlone in $1985^{5}$ and the arrest of a group of schoolchildren in 1985 who would be imprisoned in Pollsmoor Prison in 1987 after a protracted trial, and who became known as The Wynberg $7^{6}$. Two years before Gool took this photograph, two large unions were formed: The Amalgamated Clothing and Textile Workers' Union of South Africa (ACTWUSA) and the Garment and Allied Workers' Union (GAWU). This image represents the pageant at a time of the emergence of a single national body as a result of the unions' amalgamation into the Southern African Clothing and Textile Workers' Union (SACTWU). This photograph means too that these five women represent a fraction of the nearly 200000 members of the union in 1989, which in turn represented $80 \%$ of workers of the sector (Alegi 2008:34). What the union couldn't unfortunately afford these members, however, was job stability.

By 2019, Cape Town mayoral committee member for economic opportunities and asset management, James Vos, was reported as saying (IOL 2019) that the clothing and textile industry in Cape Town employed only about 23600 people. It was still the second largest employer within the manufacturing sector, and the efforts of the women on the production lines contributed significantly to the city's export market, with clothing and textile products totalling R4.4 billion in 2017, he said. But, as Van der Westhuizen and the National Labour and Economic Development Institute's (NALEDI) Hameeda Deedat noted, the number of people employed in the sector had dropped from 55288 to 39512 between 1989 and 1998 (Deedat \& Van der Westhuizen, 2016: 3). Their contention is that it's impossible to overestimate

${ }^{5}$ For more on the The Trojan Horse Massacre see The Trojan Horse Massacre. 2016. Available at: https://www.sahistory.org.za/dated-event/trojan-horsemassacre (Accessed on 29 April 2019.)

${ }^{6}$ See film documentary The Wynberg 7 (O’Connell 2015) directed and produced by Siona O'Connell. 
the fallout of the job losses in a sector where $80 \%$ of the staff are women, earning just $37 \%$ of the average manufacturing wage (Esset 2003: 21). Many of these women are sole breadwinners within their families, and the paper drew attention to the consequent detrimental effect of job cuts on families and households. In addition, the authors argued, these women lost their independence and the level of recognition, 'despite the exploitation', that the minimum wage they were earning had afforded them. Those wages, the study continued, were only R282.76 a week (2006) for a qualified machinist- the lowest in the country's manufacturing scenario. Twice retrenched factory worker Sharon Peterson (2012), who took part in the Spring Queen despite the challenges of having two children, a household and work to juggle, first worked at Novel Garments before it was shut down. She moved to Monatics, and then that shut down too. In her interview with me in 2012, 1998 Spring Queen Mareldia April, said a machinist's wages were around R 800.00 a week. Those coming in new could however expect to earn just R350.00 a week.

In the words of SACTWU researcher Simon Eppel (2012), the downward shifts in tariffs on imported clothing after 1994 had plunged the industry into crisis: 'From 2003 onwards, the South African currency got stronger and then there was just the surge of imports from China. $60 \%$ of goods that come in from China come in illegally ... almost R6-billion worth of clothing value that can't be accounted for. And that was just the utter decimation of the industry'. The comments from one Ellen Arthur SA Pty Ltd worker make it clear the retrenchments are about much more than the loss of income. It's also about the loss of a factory family, shared dreams and challenges. She said in her interview (2012): 'I'm going to be 54 next month so I don't know whether I'll still be able to go into a factory. I don't know. We were like a very nice big good family together. And they are just relying on the fact that maybe there - the place can reopen in the new year. Our company closed down on 16 October. It has been a good strong company for over 40 years. And then someone came and bought the company over and then, three years down the line, we closed down. 420 workers all retrenched'.

Bearing the weight and daily challenges of the tumultuous times and challenging conditions, these women, all dressed up with carefully styled hair for the Spring Queen spectacular, square up to their histories and realities in terms of race, gender and labour. April (2012) put it as follows: 'When you go into the factory it's all about an overall. You don't dress up because why, you're working with clothes. And all of a sudden, when it's Spring Queen, you 


\section{Siona O’Connell}

show who you are. From a cleaner I went to a machinist. From a machinist I went to an instructor. After five years, suddenly they call out Mareldia April, Spring Queen of the year 1998. I say 'Wow! Me?' They said, 'Yes it's you', and it was really a fantastic day that day'. It's an event that is not about who is the most beautiful, or who has the prettiest dress, Fachmy Abrahams (2012) said in her interview. Rather, it is aspirational: '(The winner) is the one who portrays the best aspirations of clothing workers. The kind of brief we provide for the judges is ... we say to them, 'It doesn't have to be the most beautiful girl ... doesn't have to be the girl with the best dress on. It's someone that represents the aspirations that every young girl has ... every clothing worker who wishes they can be on the red carpet ... who wishes they can wear the best dress ... who wish they can transform (from how) they look every day. This is what they transform into ... someone that can represent (the entire family of clothing workers and their families). Someone who carries that kind of pride in them that says "I can transform, but I'm a clothing worker".

\section{Race, Performance and Representation}

My first personal experience of attending a Spring Queen qualifying event, in 2012 at the Pals factory from where my paternal aunt had recently retired and my paternal uncle still worked, saw me arrive with all my preconceived ideas about the problematics of pageants, race, performance and representation. What I found there instead was that the line-up included 'black' women, whose supporters were all 'coloured' women. When I inquired, a fellow audience member said simply: We have to support her! She is on our line! What was clear was that despite the categories into which apartheid separated them, the machine line of those making men's outerwear had the ability to prompt the consideration of new possibilities for attending to division in South Africa. At this pageant, women saw past race; their focus was what brought them together: understanding the rigours and demands of production, friendship, loyalty, sharing the indescribable pain of having a sewing machine needle pierce a fingernail, having to fulfil a quota of completed items in an allocated time, and having to step in when someone was struggling to ensure that this would still happen. Spring Queen is not anecdotal or peripheral to women of the Cape Flats. The detail and time afforded to the design of the dress, the jewellery, the fundraising for the outfit coming via hotdog and cake sales by factory workers, and the brief suspension of the cruel reality of life on the Flats, 
allows for the imagination to take flight. Abrahams (2012) elucidates: 'If you come to any Spring Queen event it is that moment, that one 10 seconds, when their representative comes onto the stage that they can scream and shout because they're proud of the place where they work at. They can say this is our factory and this is our product. This is what we do. That's our girl'.

I challenge historian Paul Johnson's view that that the pageant 'functioned as a recurring and tenacious hegemonic behavioural cult in the clothing industry, drawing tens of thousands of women into a voluntarist manufacturing process in which the desired product was the gentility associated with "royal" behaviour rather than the royalties themselves' (Cited by Alegi 2008: 37) My position is informed by more than 100 interviews with pageant participants of all ages, not one of whom enforced an idea that they were reluctant or passive, or that they did it to gain one-upmanship over anyone in their factory, or their communities. All of these women speak of a shared purpose, of leaning on one another and expanding networks. All of them spoke of what it means to have an event for women, by women. And whilst there was a level of pride in having their factory grab the crown, the support for the winner crossed all sorts of lines, including factory and race. One contestant commented that people don't know that 'just being a contestant - not even winning the Spring Queen - just to feel like you're a part of something ... it changes you. And to win, it changes you totally'. The crowning of the 2012 winner, Lumka Vumendlini, a black machinist from Khayelitsha who worked for Ellen Arthur, amplifies the point. What makes her situation particularly poignant is that the factory shut its doors unexpectedly just weeks before the final event. Management made the shock announcement to the bewildered workers at lunch time. A few months later, Vumendlini was crowned Spring Queen of a non-existent factory.

Her crowning was bittersweet. With her factory closed, she didn't have her colleagues to rally round to raise funds for her dress, to enjoy the experience of having them all contribute to ideas for her hair, dress and shoes. In the end, SACTWU hired a white gown for her shortly before the final contest at the Good Hope Centre. It was unforgettable, not least because it foregrounded the realities for women such as Vumendlini. Resembling a young Winnie Mandela, she epitomised the struggles of young black and coloured women who face a past that is relentless. In an interview soon after her crowning, when the euphoria had dissipated, she was distraught. She said: 'We were 53 in total. For me becoming number one! Shocking. It is kind of like 


\section{Siona O'Connell}

heartbreaking, because I have no factory. I am kind of like worried. Who am I going to parade for? Where and how? I wanted my workers to see me. You know: 'This is our queen'. But I have no factory. I had no one to shout for me and they were shouting for the other two girls. I'm proud of them. But there was no one for me there' (Vumendlini 2012).

A year later, the Spring Queen was held for the last time at the Good Hope Centre. This is significant in itself as the event was being evicted by the City of Cape Town and dumped on the Cape Flats (at the Athlone Stadium), an act reminiscent of the forced removals decades earlier. Vumendlini bequeathed her crown to an equally gorgeous young woman who, like her predecessors, held all the hopes and dreams of women in her industry - hopes that the fragmentary liberatory moment on the ramp could be sustained; that the stage lighting would illuminate and safeguard dreams of freedom. Vumendlini stepped away, the latest in a long line of tenacious women who had come before, and paved the way for her.

\section{Conclusion}

In these outfits and immaculate shoes, it is impossible to view the Spring Queen contestants as victims. On the contrary, the pageant has been determined by its participants to be one of self-organisation and empowerment, in addition to showcasing the South African clothing and textile industry. I propose, therefore, that it is the act of self-representation and a performance of freedom on the ramp that elevates this event to one of significance. The shift from the factory worker in a dustcoat on the machine line to an unrecognisable woman in a flamboyant dress on the stage is a transformative one, a shift that challenges the apartheid dictum that black and coloured women are women of 'lack'. Spring Queen challenges the pervasive sense of shame that accompanies 'colouredness', a shame that results from illicit sexual relations during colonial times, slavery and their offspring, apartheid.

The pageant is particularly important for understanding ways of life in apartheid South Africa, when the dictum of racial superiority was legislated across all spheres. It is equally important in the post-apartheid landscape where these legacies persist. Spring Queen confronted apartheid in a spectacular, sequined, boisterous and coiffed fashion. To those who were involved in any way in the production, it is impossible to ignore the call of the worker: I am here, I matter and in this moment at the end of the ramp, I am not what you legislate me to be. 
Struggle, Freedom and the Women of the Clothing and Textile Industry

\section{References}

Alegi, P. 2008. Rewriting Patriarchal Scripts: Women, Labour and Popular Culture in South African Clothing Industry Beauty Contests, 1970s 2005. Journal of Social History Fall, 42, 1: 31 - 56.

Available at: http://muse.jhu.edu.uplib.idm.oclc.org/article/247656

https://doi.org/10.1353/jsh.0.0070

Bell, T. 2012. Hope amid the Horror of Joblessness and Exploitation. In News \& Views by Terry Bell. Available at:

https://terrybellwrites.com/2012/07/19/hope-amid-the-horror-ofjoblessness-and-exploitation/

Bogues, A. 2010. Empire of Liberty: Power, Desire and Freedom. Hanover, NH: University Press of New England.

https://doi.org/10.1349/ddlp.698

Charles, M. 2019. City of Cape Town Moves to Mend Frayed Ggarment and Textile Industry. Independent Online. Available at:

https://www.iol.co.za/capeargus/news/city-of-cape-town-moves-tomend-frayed-garment-and-textile-industry-25444467

Deedat, H. \& C. Van der Westhuizen. 2006. The Socio-economic Impact of Trade Liberalisation and Employment Loss on Women in the South African Clothing Industry: A Cape Town Case Study. Gender in Global and Regional Trade Policy: Contrasting Views and New Research. University of Warwick. Available at:

https://warwick.ac.uk/fac/soc/pais/research/researchcentres/csgr/csgrevents/workshops/2006ws/gender_and_trade/hameda_deedat_summary. pdf

Esset, A. 2003. The Impact of Trade Liberalisation on Workers in the Textile Industry. Ecumenical Service for Socio-Economic Transformation. Economic Policy Institute.

Grunebaum, H. 2011. Memorializing the Past: Everyday Life in South Africa after the Truth and Reconciliation Commission. New Brunswick, NJ: Transaction Publishers.

Hall, S. 1982. The Rediscovery of 'Ideology': Return of the Repressed in Media Studies. In Gurevitch, M., T. Bennett, J. Curran \& J. Woollacott (eds.): Culture, Society and the Media. London: Methuen

Petersen, T. 2015. Factory Workers Ready to Blossom at Miss Spring Queen Pageant. News24. Available at: 
https://www.news24.com/SouthAfrica/News/factory-workers-ready-toblossom-at-miss-spring-queen-pageant-20151113

Shepherd, N., C. Ernstein \& D.J. Visser (eds.) 2018. The Walking Seminar: Embodied Research in Emergent Anthropocene Landscapes. Amsterdam:

ON AIR: Artist-in-Residence Program, Amsterdam University of the Arts.

Slamdien, R. 2016. The Spring Queen behind the Machine. In Seams of Society: Fashion \& Marginalised Identities.

Available at:

https://seamsofsocietyblog.wordpress.com/2016/04/15/the-spring-queenbehind-the-seams/

Van der Westhuizen, C. 2006. Trade and Poverty: A Case Study of the SA Clothing Industry. Trade and Poverty Project, Southern Africa Labour and Development Research Unit, University of Cape Town. Available at: http://www.tips.org.za/files/trade_vanderwesthuizen.pdf

Yule, P. (dir.) \& S. O’Connell (prod). 2012. Spring Queen. Film. Cape Town:

Centre for Curating the Archive, University of Cape Town.

\section{Interviews}

Abrahams, F. Union Official, SACTWU. 2013. Interview by author. [Transcript]. 20 August, Cape Town.

April, M. Spring Queen 1998. 2013. Interview by author. [Transcript]. 10 September, Cape Town.

Eppel, S. Researcher, SACTWU. 2013. Interview by author. [Transcript]. 12 August, Cape Town.

Josephs, S. Shop steward. 2013. Interview by author. [Transcript]. 12 August, Cape Town.

Manuel, T. Former South African Minister of Finance. 2013. Interview by author. [Transcript]. 09 November, Cape Town.

O'Connell, B. Former Rector and Vice-chancellor of the University of the

Western Cape. 2015. Interview by author. [Transcript]. 12 September, Cape Town.

Peterson, S. Spring Queen Contestant. 2013. Interview by author. [Transcript]. 28 August, Cape Town.

Vumendlini, L. Spring Queen 2012. 2013. Interview by author. [Transcript]. 17 November, Cape Town. 
Struggle, Freedom and the Women of the Clothing and Textile Industry

Siona O'Connell Faculty of Humanities University of Pretoria siona.oconnell@up.ac.za 